\title{
Proliferation-Resistant Nuclear Fuel Cycles
}

\author{
D. O. Campbell \\ E. H. Gift
}




\section{DISCLAIMER}

This report was prepared as an account of work sponsored by an agency of the United States Government. Neither the United States Government nor any agency Thereof, nor any of their employees, makes any warranty, express or implied, or assumes any legal liability or responsibility for the accuracy, completeness, or usefulness of any information, apparatus, product, or process disclosed, or represents that its use would not infringe privately owned rights. Reference herein to any specific commercial product, process, or service by trade name, trademark, manufacturer, or otherwise does not necessarily constitute or imply its endorsement, recommendation, or favoring by the United States Government or any agency thereof. The views and opinions of authors expressed herein do not necessarily state or reflect those of the United States Government or any agency thereof. 


\section{DISCLAIMER}

Portions of this document may be illegible in electronic image products. Images are produced from the best available original document. 


\section{Printed in the United States of America. Available from National Technical Information Service \\ U.S. Department of Commerce \\ 5285 Port Royal Road, Springfield, Virginia 22161 \\ Price: Printed Copy $\$ 4.00$; Microfiche $\$ 3.00$}

This report was prepared as an account of work sponsored by an agency of the United States Government. Neither the United States Government nor any agency thereof, nor any of their employees, contractors, subcontractors, or their employees, makes any warranty, express or implied, nor assumes any legal liability or responsibility for any third party's use or the results of such use of any information, apparatus, product or process disclosed in this report, nor represents that its use by such third party would not infringe privately owned rights. 
Contract No. W-7405-eng-26

CHEMICAL TECHNOLOGY DIVISION

PROLIFERATION-RESISTANT NUCLEAR FUEL CYCLES

D. O. Campbel1

E. H. Gift*

*Operations Analysis and Planning Division, ORGDP.

NOTICE: This document contains information of a preliminary nature. It is subject to revision or correction and therefore does not represent a final report.

Date Puh1ished - June, 1978

Prepared by the UAK RIDGE NATIONAL LABORATORY

Oak Ridge, Tennessee 37830

operated by

UNION CARBIDE CORPORATION

for the

DEPARTMENT OF ENERGY
This report was prepared as an account of work sponsored by the United States Govemment. Neither the United States nor the United States Department of

Eutergy, nor any of their employees, nor any of their

contractors, subcontracturs, of their emplnyees, makes

any warranty, express or implied, or assumes any legal liability or responsibility for the accuracy, completeness or usefulness of any information, apparatus, product or process disclosed, or represents thai its usi would not infringe privately owned rights. 


\title{
PROLIFERATION-RESISTANT NUCLEAR FUEL CYCLES
}

D. 0. Campbel1

E. H. Gift

\begin{abstract}
The properties of plutonium containing unusually large proportions of the ${ }^{238} \mathrm{Pu}$ isotope are considered in relation to resistance to nuclear proliferation. Several fuel cycle modifications for light-water reactors are evaluated. It is shown that the 238Pu isotopic concentration can be increased substantially from the approximately $1.5 \%$ in discharged fuel from reactors operating presently. Concentrations of 8 to $10 \%$ are readily achievable, and values approaching $20 \%$ may be practical. The increased $238 \mathrm{Pu}$ content is accomplished by increasing its production by recycling $236 \mathrm{U}$ (via recycle of uranium from spent fuel) and $237 \mathrm{~Np}$, and by decreasing production of isotopes heavier than mass 238 by substituting thorium for $238 \mathrm{U}$. Impart on the fuel cycle appears to be no more severe than that from other proliferation-resistant concepts currently under consideration. The properties of such plutonium, particularly heat generation, may offer a viable deterrent to weapons use of the material by organizations without appropriate experience and technology, thereby substantially reducing the risk of nuclear proliferation.
\end{abstract}

\section{INTRODUCTION}

Early in 1977 several Union Carbide staff members independently began considering the possibility of a nuclear fuel cycle that would: produce plutonfum having a high deterrence to nuclear.weapons use. ${ }^{1,2}$ This report is an attempt to summarize and record the information that has been developed.

Fissile uranium isotopes can be "denatured" by diluting them with ${ }^{238} \mathrm{U}$, thereby increasing the critical mass beyond practicality. Since all plutonium isotopes have reasonably small critical masses, this concept is not applicable to plutonium. Any deterrent effect in this case must result from properties other than criticallly, but criticality has previously been emphasized to the virtual exclusion of any other factor.

The essential steps in the utilization of a potential weapons material exist in the recovery and fabrication of plutonium, and in the assembly, storage, and delfvery of a nuclear device. Any physical property that can be enhanced to such a degree that these steps are made more 
difficult will add some degree of deterrence toward weapons application.

There are several properties of the isotopes of plutonium that, if sufficiently enhanced, produce a composite plutonium mixture which may be a credible deterrent. These properties of (1) heat generation, (2) neutron production, and (3) radiation intensity are all naturally increased as methods are employed to increase the ${ }^{238} \mathrm{Pu}$ content in the plutonium isotopic mixture.

The concept proposed here is that a ${ }^{238}$ Pu "spike," if it can be produced in sufficient magnitude, may provide a credible, non-chemicallyremovable deterrent to the use of power reactor plutonium as a weapons material. It will be shown that reasonable modifications of the fuel cycle can result in production of plutonium çontaining some ton timcs more ${ }^{238} \mathrm{Pu}$ than in the case of the present once-through LWR cycle.

It is most significant that, if this concept is viable, a truly denatured fuel cycle can be achieved only if fuel is reprocessed. The denaturing results from the recovery and recycle of uranium and neptunium. In this context. LWR fuel reprocessing would need to be initiated to obtain neptunium and recovered uranium containing ${ }^{236} \mathrm{U}$ for use in denaturing plutonium produced in future LWRs, and, at the same time, produce a denatured plutonium stockpile high in ${ }^{238} \mathrm{Pu}$ for use in future LMFBRs.

This approach is not an absolute deterrent to the divercion of powei reactor-generated plutonium to weapons use, and it has always been clear that there is no practical absolute deterrent. However, various steps can be taken to make plutonium less attractive for weapons use. One might suggest that the problem is "solved" when a weapons production route indcpendent of power reactors is more attractive than diversion of power reactor fuel. All such considerations are clearly subjective. It is our hope that this proposal can be evaluated on the same basis as other alternatives, such as the various thorium reactor fuel cycles, ${ }^{3,4}$ recycle schemes (CIVEX), 5 improved physical security measures, or the outright exclusion of nuclear energy as a civilian power source.

The analyses that have been done in support of the use of ${ }^{238} \mathrm{Pu}$ as a denaturant have covered the following four general areas:

1. methods for increasing the ${ }^{238} \mathrm{Pu}$ content in power reactor plutonium,

2. estimates of potential heating problems,

3. radiation hazards from neutron and gamma emissions, and 
4. resulting complications to the power reactor nuclear fuel cycle.

\section{${ }^{238} \mathrm{PU}$ PRODUCTION METHODS}

Plutonium 238 is produced in nuclear reactors principally through two routes, from ${ }^{236} \mathrm{U}$ neutron capture and (to a smaller extent) from ${ }^{238} \mathrm{U}$ $(n, 2 n)$ reactions, as shown below:

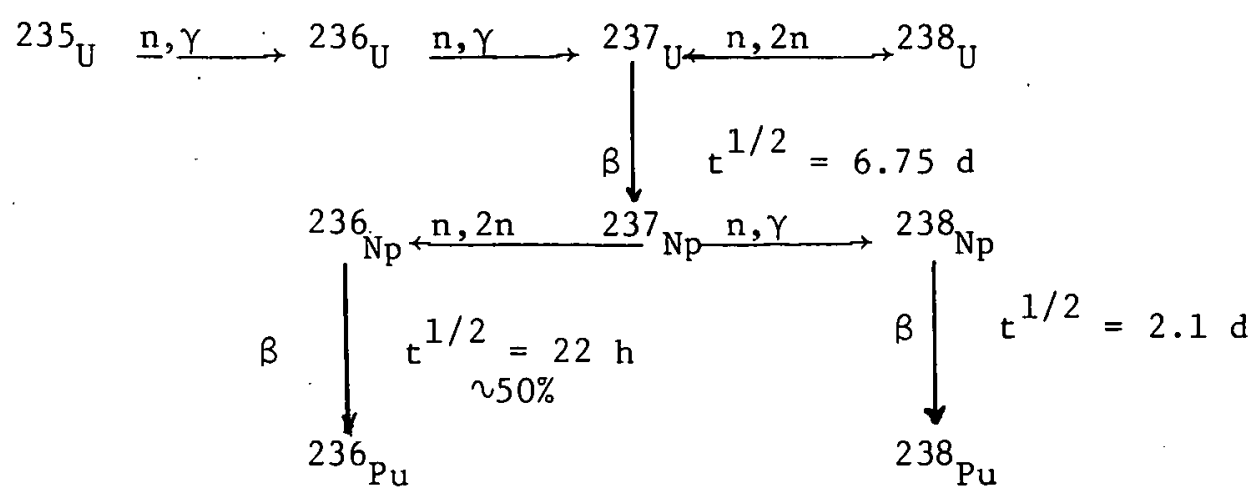

A secondary route, which will be of importance if plutonium recycle is utilized, results from the decay of ${ }^{242} \mathrm{Cm}$. This route is outlined below:

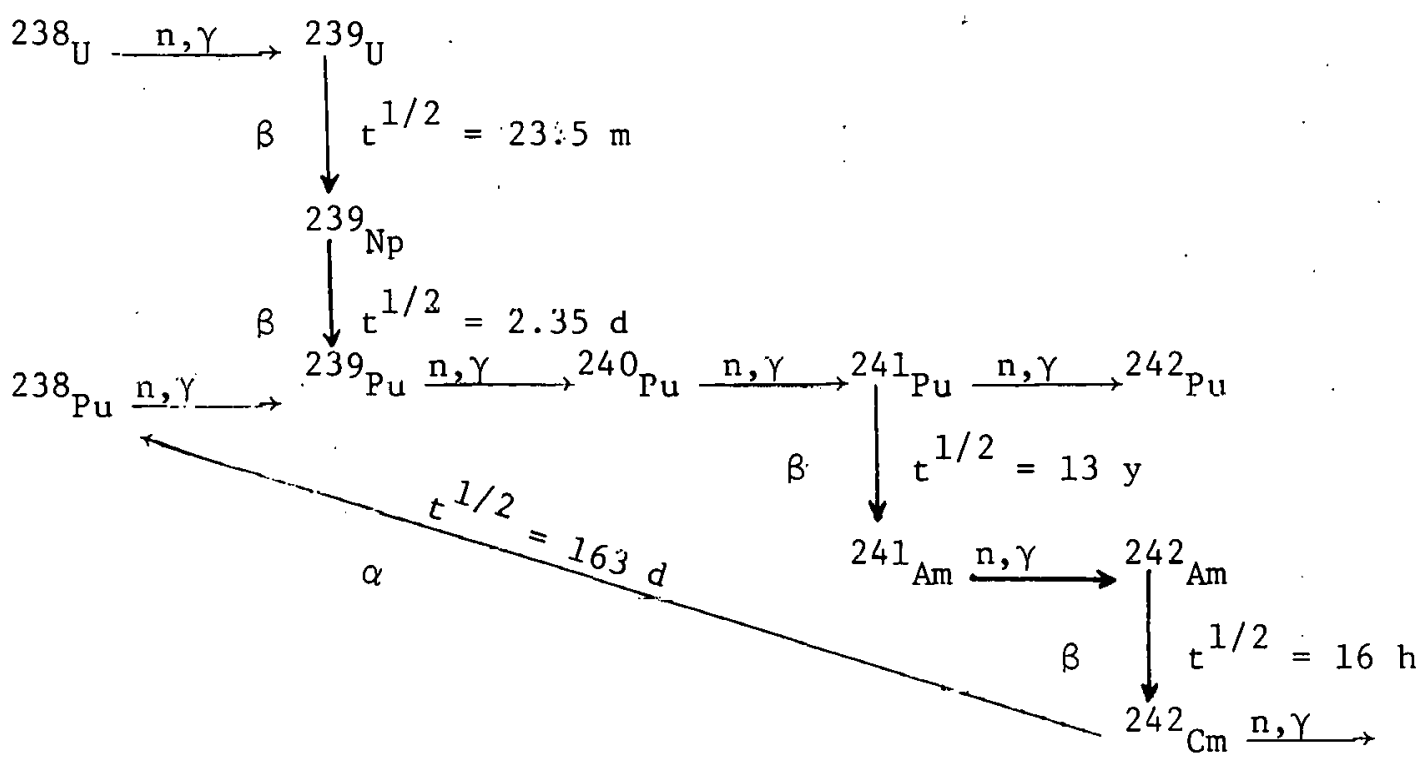


With the standard PWR once-through fuel cycle, having an initial ${ }^{235_{U}}$ enrichment of 3.2 wt \%, the discharged fuel contains about $10 \mathrm{~g}$ of plutonium per kilogram of total fuel. The ${ }^{238} \mathrm{Pu}$ concentration in the plutonium is about 1.5 wt \%. From considering the production routes, it is apparent that the ${ }^{238} \mathrm{Pu}$ fraction in the total plutonium can be enhanced if any or all of the following approaches are employed:

1. Recover and recycle the neptunium, and perhaps americium and curium isotopes (in existing flowsheets, these are routed to waste).

2. Directly recycle uranium in which the ${ }^{236} \mathrm{U}$ content is significant (present plans are to recycle uranium via enrichment, during which, under expected operating conditions, a substantial fraction of the ${ }^{236} \mathrm{U}$ is lost to tails).

3. Reduce the ${ }^{238} \mathrm{U}$ fraction in the power reactor fuel by substitution of thorium as the fertile material (this is the thorium-denatured uranium fuel cycle that has been proposed for other reasons).

Items (1) and (2) enhance ${ }^{238} \mathrm{Pu}$ production, while (3) reduces the production of isotopes heavier than ${ }^{238} \mathrm{Pu}$.

Several ways of modifying the standard fuel cycle have been considered in an effort to increase significantly the ${ }^{238} \mathrm{Pu}$ content of the resulting plutonium. Some of these are described in Table 1 . The resulting ${ }^{238} \mathrm{Pu}$. concentrations from each fuel cycle are shown in Fig. 1 . It is apparent from this figure that the ${ }^{238} \mathrm{Pu}$ concentration can be significantly increased by the choice of fuel cycle. Case 1 shows the effect of continued recycle of the ${ }^{236} \mathrm{U}$ and ${ }^{237} \mathrm{~Np}$ on the ${ }^{238} \mathrm{Pu}$ concentration in the uranium fuel cycle. Cases 2 and 5 show the additional effect of substituting thorium for some of the ${ }^{238} \mathrm{U}$, which also decreases the total plutonium production. Case 3 shows that a PWR fueled with denatured thorium breeder blanket uranium produces plutonium having much lower ${ }^{238} \mathrm{Pu}$ concentrations. Case 4 shows that, after one recycle with the thorium- ${ }^{235} \mathrm{U}$ denatured cycles, the ${ }^{237} \mathrm{~Np}$ may be withdrawn (at some reduction in proliferation resistance becauce of the ${ }^{235} \mathrm{U}$ like weapons potential of the neptunium) and used to denature other reactors, and the resulting plutonium from successive cycles will still have a high ${ }^{238} \mathrm{Pu}$ concentration. 
Table 1. PWR fuel cycle variations to increase ${ }^{238} \mathrm{Pu}$ concentration ${ }^{\mathrm{a}}$

1. Complete recycle of recovered uranium, plutonium, and ${ }^{237} \mathrm{~Np}$ from standard uranium cycle. Fissile makeup with $20 \%{ }^{235} \mathrm{U}$. The first cycle (the left end of the curve in Fig. 1) represents the oncethrough or stowaway cycle presently in effect, with a ${ }^{238} \mathrm{Pu}$ concentration of $1.47 \%$.

2. Thorium-20\% ${ }^{23} 5_{U}$ denatured cycle, with recycle of all uranium, plutonium, and ${ }^{237} \mathrm{~Np}$. Fissile makeup with $20 \%{ }^{235} \mathrm{U}$.

3. Thorium with fissile uranium from thorium breeder blanket $\left({ }^{233} U\right)$ denatured with diffusion plant tails. Recycle of all uranium, plutonium, and ${ }^{237} \mathrm{~Np}$. Fissile makeup from thorium breeder blanket uranium.

4. Thorium $-20 \%{ }^{235} \mathrm{U}$ denatured cycle, with recycle of all uranium, plutonium, and ${ }^{237} \mathrm{~Np}$, until the ${ }^{238} \mathrm{Pu}$ content is $\geq 7 \%$ in discharge plutonium; then only uranium and plutonium are recycled. Fissile makeup with $20 \%{ }^{235} \mathrm{U}$. Neptunium-237 may be recovered, under proliferation resistant conditions, for use in other reactors.

5. Thorium-20\% ${ }^{235} \mathrm{U}$ denatured cycle, with recycle of only uranium and ${ }^{237} \mathrm{~Np}$. Fissile makeup with $20 \%{ }^{235} \mathrm{U}$. Recovered plutonium may be used as denatured breeder core fuel.

$\mathrm{a}_{\text {These }}$ five scenarios are compared in Fig. 1. 


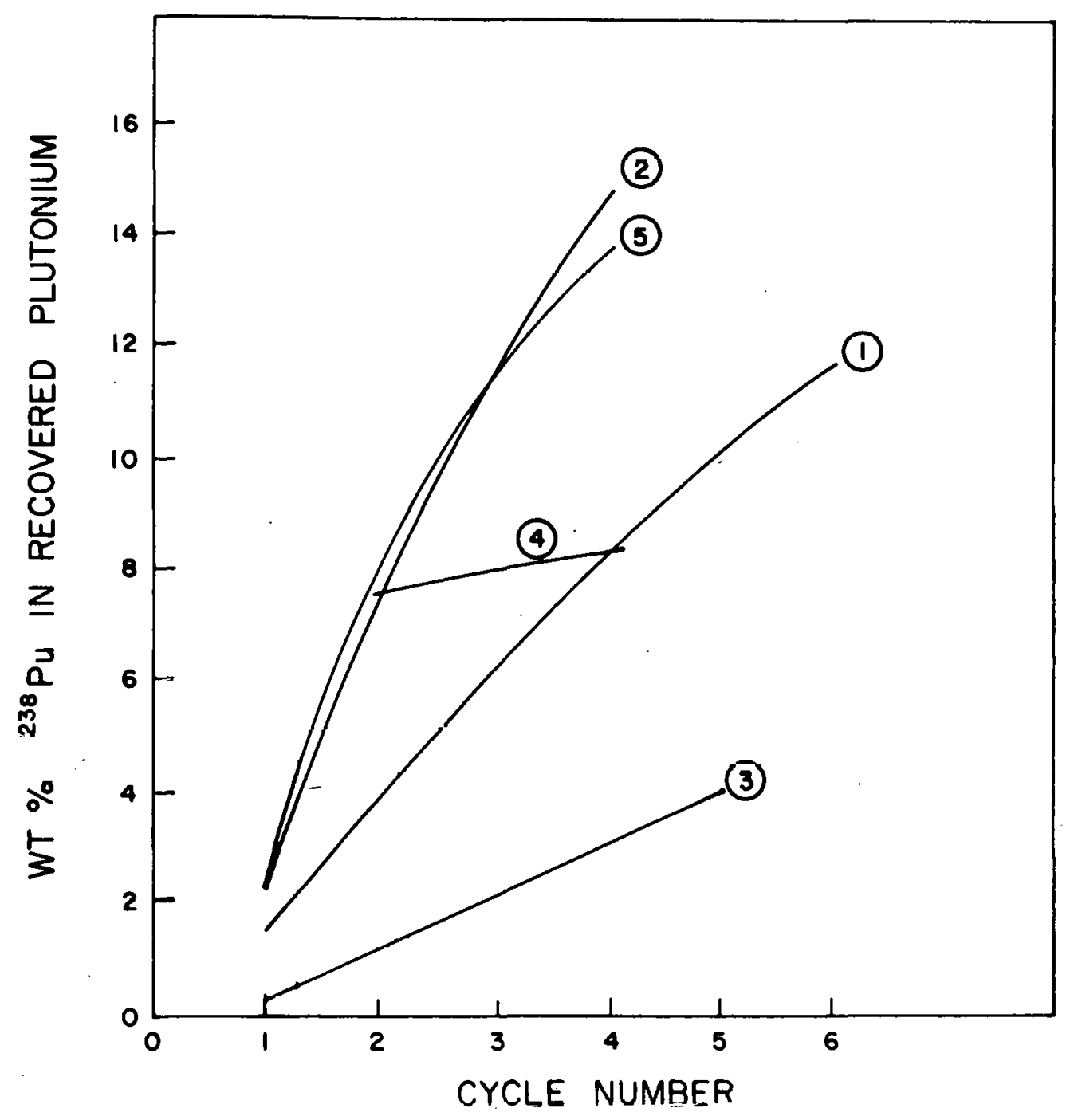

Fig. 1. Concentration of ${ }^{238} \mathrm{Pu}$ in PWR discharge plutonium for several fueling schemes. 
ORNL DWG 78-5226R

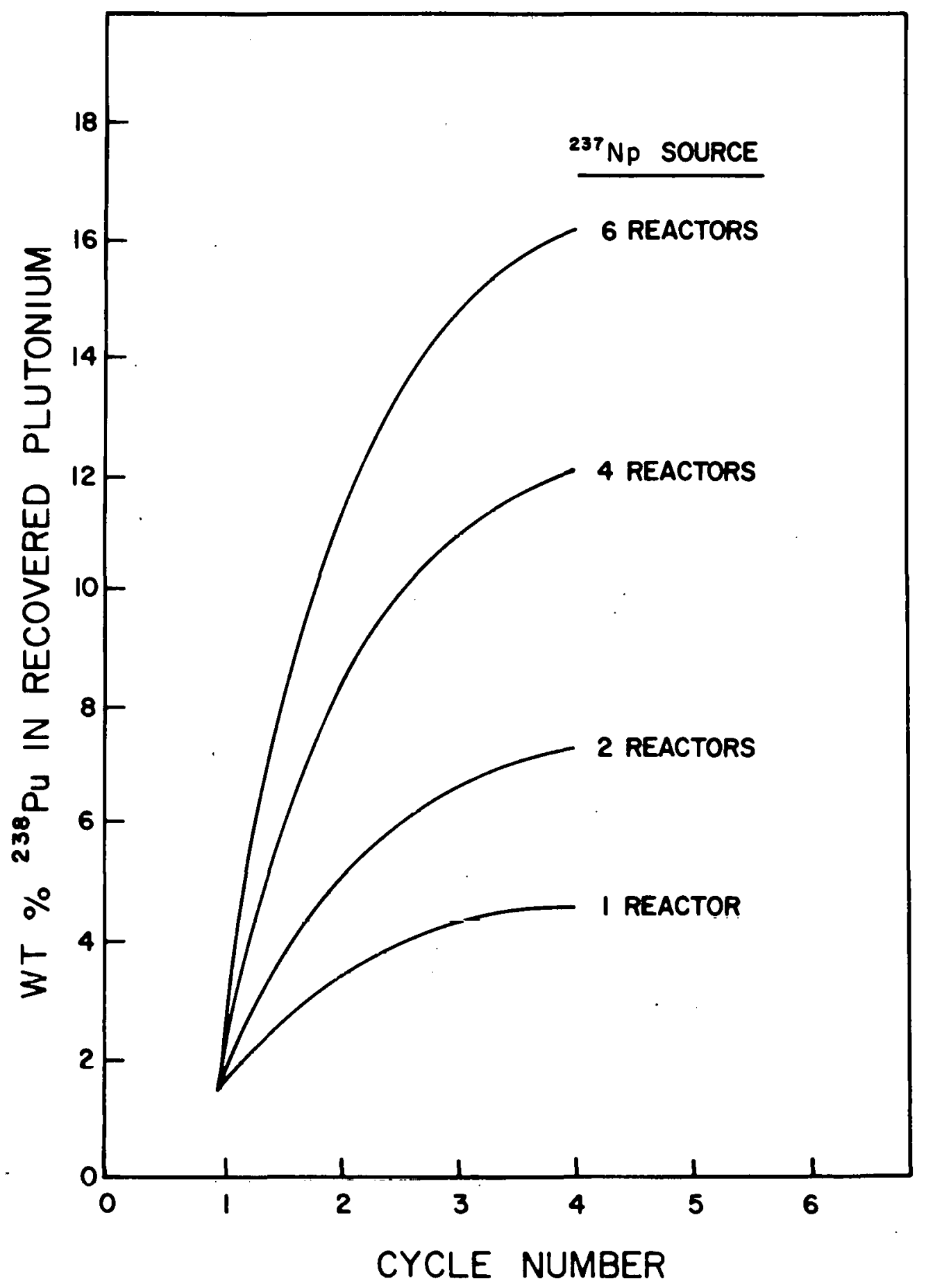

Fig. 2. Concentration of ${ }^{238} \mathrm{Pu}$ as a function of ${ }^{237} \mathrm{~Np}$ rnntributors and number of recycles. 
One could use excess ${ }^{237} \mathrm{~Np}$ by adding it to the fresh, slightly enriched uranium fuel of existing or new PWRs, so that the plutonium produced would have a higher ${ }^{238} \mathrm{Pu}$ content. This effect, which is illustrated in Fig. 2, was analyzed by assuming that the ${ }^{237} \mathrm{~Np}$ from a standard first-cycle PWR could be recovered and added to fresh fuel for other similar reactors. If the ${ }^{237} \mathrm{~Np}$ from one reactor is recycled only to itself or another single reactor, the resulting ${ }^{238} \mathrm{Pu}$ concentration is represented by the lowest curve. If the ${ }^{237} \mathrm{~Np}$ from two reactors is recycled to one reactor, the second curve results. Thus, even in this simple recycting scheme, high ${ }^{238} \mathrm{Pu}$ concentrations are quickly attainable in a fraction (approaching half) of all the reactors.

These examples show that the ${ }^{238}$ Pu content of power reactor fuel can be dramatically increased with relatively minor changes to the basic nuclear fuel cycle. Plutonium-238 contents in the range of 8 to $10 \%$ are readily achieved, and values approaching $20 \%$ may be possible. The resulting plutonium isotopic mixture, and perhaps ${ }^{237} \mathrm{~Np}$, could be recycled in LWRs or utilized as a "safe" fuel for the core of a breeder, possibly in a non-weapons nation.

\section{POTENTIAL HEATING PROBTEMS}

P1utonium-238 decays by alpha emission with an 89-year half-life. The specific heat generation is very high, i.e., $0.56 \mathrm{~W}$ per gram of ${ }^{238} \mathrm{Pu}$. Thus a $10-\mathrm{kg}$ mass of plutonium (a sphere $\sim 4 \mathrm{in}$. diam) containing $10 \%{ }^{238} \mathrm{Pu}$ would generate $560 \mathrm{~W}$ of heat. In air, a 150-W light bulb, of about the same size, ts too hot to hold. Estimates have been made of the equilibrium interface temperature of such a $10-\mathrm{kg}$ mass when 1nsulated by varying thicknesses of a typical high explosive. The resulting temperatures are far above the critical temperature of most explosives.

The isotopic compositions of plutonium from three potential fueling scenarios are presented in Fable 2. In case 1 the composition is representative of the first cycle discharge of standard PWRs, or a stowaway cycle. Case 2 represents the long-term buildup for complete recycle of uranium, plutonium, and neptunium (Scenario 1 of Fig. 1). Case 3 represents the longterm builup for the thorium- ${ }^{235} \mathrm{U}$ cycle when uranium, plutonium, and neptunium are recycled (Scenario 2 of Fig. 1). 
Table 2. Representative discharge plutonium isotopic concentrations

\begin{tabular}{llll}
\hline Isotope & Case $1^{\mathrm{a}}$ & Case $2^{\mathrm{b}}$ & Case $3^{\mathrm{c}}$ \\
\hline${ }^{236} \mathrm{Pu}$ & $1.39 \times 10^{-7}$ & $8.45 \times 10^{-7}$ & $1.29 \times 10^{-6}$ \\
${ }^{238} \mathrm{Pu}$ & 0.0147 & 0.1174 & 0.1854 \\
${ }^{239} \mathrm{Pu}$ & 0.5645 & 0.4964 & 0.3867 \\
${ }^{240} \mathrm{Pu}$ & 0.2647 & 0.2299 & 0.1877 \\
${ }^{241} \mathrm{Pu}$ & 0.1154 & 0.1251 & 0.1207 \\
$242 \mathrm{Pu}$ & 0.0407 & 0.1202 & 0.1095 \\
\hline
\end{tabular}

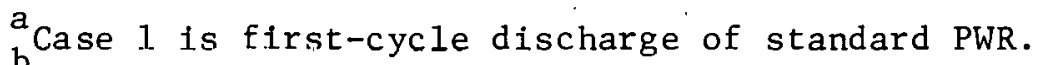

${ }^{b}$ Case 2 is fifth-generation discharge of Scenario 1 of Fig. 1 and Table 1 .

${ }^{c}$ Case 3 is fifth-generation discharge of Scenario 2 of Fig. 1 and Table 1 . 
The heat generation rates of the plutonium compositions described in Table 2 are presented in Table 3. For comparison, the heat generation rates of the fission products and actinides in spent LWR fuel are also given. The specific heat output (per gram of plutonium or of total heavy metal, respectively) is about the same for plutonium produced in present LWRs (Case 1) and for typical spent reactor fuel after one year of cooling The "denatured": plutonium of Cases 2 and 3 generates 6 to 10 times as much heat, depending on the ${ }^{238} \mathrm{Pu}$ content.

A sufficiently ingenious organization with a highly developed technology could conceivably make a weapon out of plutonium which self-generates such amounts of heat. At the very least, though, the metal purification, shaping, and assembly steps of manufacture would become sufficiently difficult, and re-storage and delivery of the weapon so uncertain, that a fledgling weapons-maker might choose some other route. In principle, such problems may be circumvented by elaborate technology, but this technology is clearly beyond the capability of the unsophisticated weapons-maker, thereby providing an effective deterrent with respect to terrorists, criminal groups, and developing nations. Such technology, for the higher ${ }^{238} \mathrm{Pu}$ contents, may well be beyond the capability of all but experienced weapons design teams, thereby solving the deterrent problem in total since they already have weapons capability. In any case, other fissile materials would be more desirable.

\section{NEUTRON AND GAMMA RADIATION}

It is well known that the isotopes of plutonium are radioactive; a11 except ${ }^{241} \mathrm{Pu}$ (a beta emitter) decay by alpha emission. Additionally, all of them, especially the even-mass isotopes, have significant spontaneous fission rates. Further, in the presence of light elements (e.g., oxygen and fluorine), a significant $(\alpha, n)$ reaction occurs. The isotopes ${ }^{236} \mathrm{Pu}$ and ${ }^{241} \mathrm{Pu}$ also decay to daughters having high gamma activities. It is apparent that nearly all of the radiation characteristics are made more troublesome as the ${ }^{238}$ Pu concentration i.s increased.

Table 4 presents the estimated gamma radiation dose rates at a distance of $1 \mathrm{ft}$, as a function of time after purification of a $10-\mathrm{kg}$ mass of plutonium metal for each of the three cases described above. 
Table 3. Decay heat generation rates

\begin{tabular}{llc}
\hline Material & $\frac{\text { Watts per gram after cooling times of }}{2}$ & \\
\hline Discharged fuel: & & 0.00555 \\
Fission products & 0.0106 & 0.00033 \\
Actinides & 0.00054 & 0.0059 \\
Total & 0.0111 & 0.0117 \\
Purified plutonium: & 0.0116 & 0.0689 \\
Case $1^{\mathrm{b}}$ & 0.0685 & 0.107 \\
Case $2^{\mathrm{c}}$ & 0.106 & \\
Case $3^{\mathrm{d}}$ & & \\
\hline
\end{tabular}

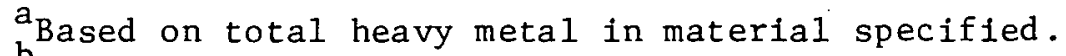

${ }^{b}$ Case 1 is first-cycle discharge of standard PWR.

chase 2 is fifth-generation discharge of Scenario 1 of Fig. 1 and Table 1.

${ }^{d}$ Case 3 is fifth-generation discharge of Scenario 2 of Fig. 1 and 'Iable 1 . 
Table 4. Gamma radiation dose rate (in $\mathrm{mR} / \mathrm{hr}$ ) at $1 \mathrm{ft}$ from a 10-kg plutonium sphere

\begin{tabular}{cccc}
\hline $\begin{array}{l}\text { Time } \\
\text { (days) }\end{array}$ & Case $1^{\mathrm{a}}$ & Case $2^{\mathrm{b}}$ & Case $^{\mathrm{c}}$ \\
\hline 0.5 & 25 & 126 & 191 \\
5 & 26 & 126 & 191 \\
30 & 27 & 127 & 192 \\
90 & 30 & 130 & 195 \\
183 & 34 & 135 & 200 \\
365 & 43 & 145 & 209 \\
1095 & 79 & 183 & 245 \\
\hline
\end{tabular}

${ }^{a}$ Case 1 is first-cycle discharge of a standard PWR.

${ }^{b}$ Case 2 is fifth-generation discharge of Scenario 1 of Fig. 1 and Table 1 .

Case 3 is fifth-generation discharge of Scenario 2 of Fig. 1 and Table 1 .

Table 5. Neutron dose rate (mrem/hr) at 1 f.t from 1n-kg spheres

\begin{tabular}{lccc}
\hline & Case $1^{\mathrm{a}}$ & Case $2^{\mathrm{b}}$ & Case $3^{\mathrm{c}}$ \\
\hline Plutonium oxide & 119 & 446 & 640 \\
Plutonium metal & 131 & 259 & 300 \\
\hline
\end{tabular}

${ }^{a}$ Case 1 is first-cycle discharge of a standard PWR.

${ }^{b}$ Case 2 is fifth-generation discharge of Scenario 1 of Fig. 1 and Table 1 .

${ }^{c}$ Case 3 is fifth-generation discharge of Scenario 2 of Fig. 1 and Table 1 . 
Table 5 presents the corresponding neutron dose rates also at a distance of $1 \mathrm{ft}$ from 10-kg plutonium oxide or metal spheres. These rates are essentially independent of time, although small changes would be observed, primarily resulting from the $(\alpha, n)$ reaction from the buildup of ${ }^{241} \mathrm{Am}$. A significant portion of this neutron dose results from neutron multiplication within the plutonium mass. The contribution of fission gammas has not been included in the estimates of gamma dose in Table 4. From Tables 4 and 5 it is apparent that most of the biological dose from handling kilogram quantities of plutonium will result from neutrons, but the rates are low enough that, by themselves, they do not provide an effective deterrent. However, the high neutron emission would cause weapon yields to be uncertain and strongly favors the realization of "fizzle" yield.

\section{COMPLICATIONS TO THE POWER REACTOR FUEL CYCLE}

The fuel cycle modifications suggested in this work are reasonably modest and involve little extension of projected technology. This is especially true if the thorium-denatured uranium cycle is considered as the base fuel cycle. These modifications are anticipated to increase the fuel cycle cost beyond that projected for a traditional plutonium recycle mode. Complications would be introduced in the following portions of the nuclear fuel cycle:

1. Shipment and handling of unirradiated mixed oxide fuel would become more difficult, but not nearly as difficult and expensive as for highly gamma spiked recycle fuel or spent fuel.

2. The greater amounts of ${ }^{238} \mathrm{Pu}$ would make it necessary to reexamine licensing and the environmental restrictions on all portions of the fuel cycle.

3. Nearly all portions of the LWR nuclear fuel cycle will be more expensive than the corresponding traditional plutonium recycle mode. These added cost's would be especially apparent in enrichment, natural uranium, shipping, and fabrication. Smaller added costs would be incurred in reprocessing and waste handing. However, other suggested proliferation-resistant fuel cycles may also have significant impacts. 
4. Fuel reprocessing would require the (partial) coprocessing of uranium and plutonium, primarily to keep specific heat and radiation levels in recovered products as low as possible and to utilize all of the ${ }^{236} \mathrm{U}$ in new fuel loadings. Neptunium, and possibly americium and curium, would be recovered either with the coprocessed uranium and plutonium or separately. The increased ${ }^{238} \mathrm{Pu}$ content would present some problems in reprocessing. The alpha radiation intensity of one-year-cooled fuel would be greater by up to a factor of 2 , but the total radiation decay energy (including fission products) would be increased by less than $10 \%$. Such radiation levels are expected to be manageable, especially with some degree of coprocessing which dilutes plutonium with uranium.

5. Fuel fabrication of plutonium-bearing fuels would require fully remotely operated facilities (which may be required in any recycle case). In refabrication of $20 \%$ plutonium- $-80 \%$ mixed oxide fuel, the specific alpha and heat generation rates would be about $1.5( \pm 0.4)$ times as great as from conventional LWR firstcycle plutonium. This is not expected to have a significant impact. In contrast, serious problems would be anticipated if the plutonium were concentrated into a reasonably pure and concentrated product, because the heat generation rate would be 5 to 10 times greater than for LWR first-cycle plutonium. 
1. E. H. Gift, R. E. Perry, and R. G. Wymer, Patent disclosure CNID-3595 entitled, "Proliferation Deterrent Plutonium for Nuclear Reactors" (April 1, 1977).

2. D. 0. Campbe11, Patent disclosure CNID-3613 entitled, "Proliferation Deterrent Plutonium for Nuclear Reactors" (April 1977).

3. T. Greenwood, H. A. Feiveson, and T. B. Taylor, Nuclear Proliferation: Motivations, Capabilities, and Strategies for Control, McGraw-Hill, New York, 1977.

4. D. E. Bartine et al., Interim Assessment of the Denatured ${ }^{233} \mathrm{U}$ Fuel Cycle, Feasibility and Non-proliferation Characteristics (to be published).

5. M. Levinson and E. Zebroski, "A Fast Breeder System Concept, A Diversion Resistant Fuel Cycle - CIVEX," presented at the 5th Energy Technology Conference, Washington, D. C., Feb. 27, 1978. 


\section{THIS PAGE}

\section{WAS INTENTIONALLY LEFT BLANK}


ORNL/TM-6392

\section{INTERNAL DISTRIBUTION}

1. W. B. Arthur

2. D. E. Bartine

3. J. T. Bradbury

4. R. E. Brooksbank

5. K. B. Brown

6. W. D. Burch

7-11. D. 0. Campbe11

12. C. F. Colleman

13. A. G. Croff

14. M. J. Feldman

15. D. E. Ferguson

16. R. B. Fitts

17. A. J. Franke1

18. A. de la Garza

19-23. E. H. Gift

24. J. M. Googin

25. A. T. Gresky

26. W. S. Groenier

27. W. 0. Harms

28. R. F. Hibbs

29. P. R. Kasten

30. R. E. Leuze

31. A. L. Lotts

32. F. C. Maienschein

33. A. P. Malinauskas
34. J. D. McGaugh

35. K. J. Notz

36. J. P. Nichols

37. R. E. Perry

38. H. Postma

39. C. D. Scott

40. I. Spiewak

41. D. B. Trauger

42. P. R. Vanstrum

43. B. L. Vondra

44. R. P. Wichner

45. W. J. Wilcox

46. R. G. Wymer

47. Laboratory Records, RC

48-52. Laboratory Records

53-54. Central Research Library

55. Document Reference Section

56. G. R. Choppin (Consultant)

57. L. J. Colby (Consultant)

58. E. L. Gaden (Consultant)

59. L. E. Swabb (Consultant)

60. K. D. Timmerhaus (Consultant)

61. ORNL Patent Section

EXTERNAL DISTRIBUTION

62. R. J. Hart, DOE, ORO

G3. E. G. KisPr, DOE, ORO

64. M. M. Dare, DOE, ORO

65. R. L. Philippone, DOE, ORO

66. W. W. Ballard, DOE, Washington, D. C.

67. W. A. Voigt, DOE, Washington, D. C.

68. G. W. Cunningham, DOE, Washington, D. C.

69. E. Delaney, DOE, Washington, D. C.

70. W. Scheib, DOE, Washington, D. C.

71. R. Beatty, DOE, Washington, D. C.

72. E. S. Beskjnrd, DOE; NPD, Washington, D. C.

73. Research and Technical Support Division, DOE-ORO, P.O. Box F, Oak Ridge, TN 37830

74-100. Technical Information Center, Oak Ridge. TN 37830 